\title{
The Impact of Islamic Banks on the Gross Domestic Product (GDP): An Empirical Study in Dubai
}

\author{
Baaeth Atallah Aldalaien ${ }^{1}$ \\ ${ }^{1}$ College of Business Administration, Ajman University, UAE \\ Correspondence: Baaeth Atallah Aldalaien, College of Business Administration, Ajman University, UAE. E-mail: \\ Baethdl@yahoo.com
}

Received: January 28, 2019

Accepted: February 18, 2019

Online Published: March 8, 2019

doi:10.5539/ijbm.v14n4p135

URL: https://doi.org/10.5539/ijbm.v14n4p135

\begin{abstract}
The present study aimed to explore the impact of Islamic banks on the gross domestic product (GDP) in Dubai. A descriptive analytical approach was adopted. In order to meet the study's goals, the researcher reviewed the relevant theoretical literature and previous studies. Questionnaire forms were distributed to the selected sample. The sample consists from 100 employees. They were selected from the credit facilities department of two Islamic banks located in Dubai. It was found that Islamic banks and finance can significantly raise the gross domestic product (GDP). It was found that the Islamic banks can significantly raise the gross domestic product (GDP) of the United Arab Emirates (UAE) in general and Dubai in particular. The researcher recommends developing and innovating new funding, banking and investment products in the aim of meeting the demands of customers. These products mustn't violate the provisions of Sharia (Islamic law). In addition, the researcher recommends using the modern technologies and skills at banks. That shall participate in achieving development.
\end{abstract}

Keywords: Islamic Banks, Gross Domestic Product (GDP), Dubai

\section{Introduction}

The attention provided to Islamic financial products has been increasing recently. The demand on such products has been increasing too. That applies to the financial services and instruments traded in the Islamic financial market. The latter demand has been increasing because the Islamic financial products are characterized with having a high funding efficiency level when funding investment enterprises. These products enable the owners of enterprises to handle crises. They participate in achieving social and economic development in developing and developed countries. It should be noted that the Islamic financial products comply with the economic provisions and principles of Sharia (Islamic law) (Zagh'lami \& Kamal, 2018).

Achieving economic development is a goal sought in an ongoing manner by most countries. It should be noted that the process carried out for such achievement is a comprehensive process. For instance, it involves cultural, social, economic and etc... aspects. In order to meet the development-related goals in developing countries, much attention has been provided to the development of the private sector. When shedding a light on the development of the private sector, one must shed a light on funding issues. That is because the private sector in all countries in general and developing countries in particular suffers from the lack of funding. In order to overcome this problem, the developing countries seek re-constructing the structure of their national economic. They also seek developing strategies for achieving development. That shall participate in achieving economic growth (Mashbab, 2015).

The Islamic finance sector has been developing rapidly, especially in the member-countries of the Organization of Islamic Cooperation (OIC). In addition, the number of Islamic banks has been increasing, especially in the United Arab Emirates. In 2017 in Malaysia, the rates indicate that Islamic finance is more dominant than conventional finance. In Malaysia and the United Arab Emirates, the Islamic finance has become as the main driving force for developing the national banking system. It has become considered so in the countries located in Central Asia and Eastern Africa. It has become so because governments have been providing much to promote financial inclusion and ensure that the issued in0struments remain valuable.

One of the achievements of the Gulf Cooperation Council in 2017 is the issuance of instruments that are pegged to USD for the first time. Their value is 1 billion USD. In 2017. The value of the assets in one of the flourishing 
sectors is 2.4 billion USD approximately. It's expected that the latter value will increase to become 3.8 billion USD approximately by 2023 (Abu Shamaleh, 2018).

\subsection{Statement of the Problem}

The Islamic finance is considered one of the pillars needed for carrying an economic activity. It's considered one of the pillars needed for achieving economic development in many countries, especially in Islamic countries. It should be noted that Islamic finance can significantly participate in achieving economic development. That's done through offering several Islamic finance products, such as: Murabaha, Mudaraba or Musharakah. Through such products, the Islamic finance sector shall participate in developing the sectors that investors seek investing in.

The problem of the present study is represented in the following question: What's the impact of Islamic banks on the gross domestic product (GDP) in Dubai?

\subsection{The Study's Significance}

The present study is significant because it aimed to shed a light on significant issues. These issues include: the extent of contribution of Islamic banks in the economic development process. These issues include: the impact of the Islamic banks' investments on the gross domestic product. The present study is significant because Islamic finance plays an important role in achieving economic development. It plays such a role because most people in Islamic communities are concerned in dealing with financial institutions that enforce the provisions of Sharia (Islamic law) on their transactions. To ensure compliance with the latter provisions, the Islamic banks adopt codes that are based on the latter provisions.

The Islamic banks participate in achieving economic development through providing several Islamic finance products, such as: Murabaha, Mudaraba and Musharakah. Through such products, the Islamic banks enable people to carry out financial and business transactions. The present study is significant because it aimed to shed a light on a significant issue. This issues is represented in the impact of the Islamic bank finance on an economic variable (i.e. the gross domestic products).

The present study is significant because the duties assigned to the Islamic banks have been increasing. These duties are assigned to them for achieving development. The present study is significant because many private organizations rely on the credit services and programs provided by Islamic banks. However, in order for the Islamic finance sector to meet the intended goals, it must provide the economic sectors with effective credit services and programs.

\subsection{The Study's Objectives}

The present study aimed to explore the impact of Islamic banks on the gross domestic product (GDP) in Dubai. The researcher aimed to achieve that through reviewing the relevant theoretical literature and previous studies. These studies shed a light on Islamic finance and its relationship with economic variables, such as the gross domestic product (GDP).

\subsection{The Study's Hypothesis}

Ha.1) - Islamic banks have a statistically significant impact on the gross domestic product (GDP) in Dubai.

\subsection{The Study's Theoretical Framework}

Banks play a significant role in achieving economic development. That's because banks provide customers with credit services to fund enterprises. In order for banks to achieve economic development, the value of their credit must exceed their cash reserve, paid-up capital, and deposit values. In this context, deposit includes: existent and former savings. Deposits are used by banks for granting loans to customers. They are used by banks to provide investors with loans for supporting investments. Providing investors with loans shall participate in achieving economic expansion in all areas. Thus, it shall participate in achieving economic development (Al-Rafeeq, 2002).

Islamic banks are characterized with carrying out banking transactions in a manner that differs from the other conventional banks. The transactions of Islamic banks are based on sharing profits and losses with customers and forming partnerships with customers in enterprises through investing money or labor. The transactions of Islamic banks include: Murabaha, Mudaraba, Muzara'a (Note 1) and Istisna (Note 2). It should be noted that Islamic banks don't conduct transactions like the other conventional banks. That's because the Islamic banks refuse to grant interest-based loans (Al-Beka'i, 2014).

The Islamic finance sector plays an outstanding role in the field of securities' investment. It has been attracting 
many investors, including Muslim investors. Therefore, most of the ones who issue securities in the conventional financial markets started to issue Islamic products. They started to do that in the aim of attracting customers, and increasing the extent of Islamic securities exchange (Al-Nouri, 2009).

In comparison to conventional banks, Islamic banks emerged recently. To be specific, Islamic banks emerged in 1940s. At the beginning, the Islamic banks were concerned in providing people with savings funds that are interest-free. The first couple of Islamic banks were established at Pakistan and Malaysia in 1940 and 1950 respectively. After that, the first Islamic saving bank in Egypt failed. The latter bank used to operate in accordance with the provisions of Sharia (Islamic law). Later on, Naser Social Bank was established in Egypt in 1972. The latter bank is non-Ribawi bank. After that, the first Islamic bank in Dubai was established in 1975. The latter bank has been achieving much success. It complies with the provisions of Sharia (Islamic law). After that, the Islamic Development Bank was established. Then, Faisal Islamic bank in Sudan, Kuwaiti Finance House, Faisal Islamic bank in Egypt, Dalet Al-Barakeh Bank and Bait Al-Mal Al-Islami were established. After establishing such banks, the number of Islamic banks started to increase in the five continents (Al-Beka'i, 2014).

It can be noticed that many governments allowed the establishment of Islamic banks through issuing legislations. For instance, the Malaysian Parliament issued in 1982 the Islamic banks act. In Pakistan, the Islamic banking system act was enacted in 1979. In 1983, the Islamic banking act was enacted in Iran. In turkey, the non-Ribawi (Note 3) finance act was enacted in 1983. The institutions that operate in the Islamic finance sector in Turkey are called (private finance houses) (Al-Tamimi \& Al-Sanfi, 1995).

The Islamic banks and Islamic finance institutions are characterized with serving as a financial intermediary. They use Islamic financial instruments in the aim of generating profits in accordance with the provisions of Sharia (Islamic law). That means that an Islamic bank adopt an Islamic finance code. There are three methods that Islamic banks and Islamic finance institutions may use for carrying out their transactions. The first method is direct finance. It involves free-interest loan and Mudaraba. The second method is represented in indirect finance. It involves Murabaha, credit sale and all types of Ijarah (including the type in which the legal title is transferred to the lessee after the contract expires). The third method is represented in financing through providing services. This method involves Istisna' and etc.. The Islamic banks and Islamic finance institutions are characterized with providing profits based on a changing profit rate. Thus, they don't provide Ribawi profits. In the light of the aforementioned, it can be concluded that Islamic finance products differ from the Ribawi finance products in terms of nature and effect (Al-Asali, 1998).

Similar to other institutions, the Islamic banks provide investment services on the medium-term. The latter banks can encourage people to save money in order to invest it through various investment channels. The survival of Islamic banks is affected by the extent of success achieved by their investment channels and tools. In other words, their investment channels serve as their backbone. The Islamic banks carry out investments through three methods. These forms are: 1)-the bank management shall serve as a main investor in enterprises of high feasibility, 2)- the bank management shall serve as a co-partner in enterprises of high feasibility 3)- the bank management shall serve as a financial intermediary between the owners of funds (depositors) and investors (speculators) (A-Rafeeq, 2002).

The Islamic banks are significant due to the following reasons (Khalaf, 2006):

1- These banks enforce the provisions of Sharia (Islamic law) on their banking services and transactions. That applies whether their transactions involve money or goods. Their transactions and operations are free from riba, exploitation and aleatory.

2- These banks aim to achieve social and economic development. They believe that social and economic development are connected with one another. They believe that achieving social development is required for achieving economic development

3- These banks aim to fight against the inflation problem. That is done through refraining from conducting Ribawi transactions. These banks calculate the return of deposits through taking into consideration the actual profits gained from the investments. They prevent providing people with illegitimate profits resulting from inflation. Conventional banks provide their businessmen clients with such illegitimate profits through providing them with long-term loans. Refraining from Ribawi transactions shall participate in improving the quality of the transactions conducted in the financial markets.

4- These banks utilize the surplus of frozen funds. That's done through investing it in their developmental enterprises. That includes agricultural, industrial, or service enterprises. Therefore, Islamic banks serve as significant tool for encouraging people to save money and investing it in legitimate methods 
5- These banks provide convenient banking alternative products. They seek achieving customer satisfaction through proposing finance products that can attract all people. Such products include: Mudaraba, Musharakah, Ijarah and etc.. These banks encourage people to save money. They seek using customers' money to finance infrastructure projects which possess high feasibility on the social and economic levels.

\subsection{Islamic Banks and Finance in the United Arab Emirates}

Based on the statistics published by Dubai Center for Statistics, the Islamic economic institutions' contribution in the gross domestic product (DDP) of Dubai is $8.3 \%$. This rate was calculated based on the measurement indicators used by the latter center. In this context, the Islamic economy involves several sectors; the business sector, the Islamic finance sector and the transformative industries sector. The rate that represents the contribution of the Islamic financing activities in the gross domestic product in Dubai has been rising. For instance, the latter rate in 2014 is $22.2 \%$. It is $24.7 \%$ in 2015 . It's $26.3 \%$ in 2016 .

Based on the data published by Dubai Center for Statistics, the rate that represents the contribution of the Islamic economic sectors in the gross domestic product in Dubai has been rising. For instance, the latter rate in 2014 is $7.6 \%$. It became $8.3 \%$ in 2016 . Thus, it rose by a rate of $14 \%$. The latter contribution is represented in 32.77 billion Emirati dirham in 2016. It is represented in 28.78 billion Emirati dirham in 2014.

Based on the data published by the UAE Banks Federation (UBF), the amount of fund that the Islamic banking sector provided to finance resident and non-resident customers reached 20 billion Emirati dirham by the end of November, 2018. The latter sector consists from 8 banking and financial intuitions that are licensed by the Central Bank. The volume of the finance portfolio of the latter sector reached 454 billion Emirati dirham by the end of 2018. However, before that, that volume was 374 billion Emirati dirham. Thus, it rose by a rate of 5.6\%.

The Islamic banks have been providing much attention to the private sector, especially the private business and industrial sectors. For instance, the Islamic banks increased the amount of funds provided to finance the private sector by a rate of $5.9 \%$. This amount reached 297.4 billion Emirati dirham by the end of 2018. The Islamic banks increased the amount of funds provided to finance the private business and industrial sectors by a rate of $8.9 \%$. The latter increase is represented in 13.6 billion Emirati dirham. To be specific, the amount of funds provided by Islamic banks to finance the private business and industrial sectors reached 165.7 billion Emirati dirham by the end of 2018. The latter amount represents $44.3 \%$ of the overall volume of the finance portfolio of all the financial banking institutions. The latter amount (i.e. 165.7) represents $55.7 \%$ of the overall amount of funds that is provided to finance all the various types of private enterprises.

The amount of funds provided by Islamic banks to finance non-resident customers has been rising significantly. It rose by a rate of $12.7 \%$. By the end of November, 2018, the latter amount reached 27.5 billion Emirati dirham. However, the amount of funds provided by Islamic banks to finance the public enterprises has decreased by a rate of $4.2 \%$. The latter amount reached 31.6 billion Emirati dirham by the end of 2018. The amount of funds provided by Islamic banks to finance the enterprises of financial non-banking institutions has decreased by a rate of $5.1 \%$. The latter amount reached 3.7 billion Emirati dirham by the end of 2018 .

The amount of funds provided by Islamic banks to finance individuals witnessed an increase during the beginning of 2018 by a rate of $2.3 \%$. However, the latter amount decreased by the end of November, 2018 by a rate of $0.9 \%$. The latter amount reached 131.7 by the end of November, 2018. Based on the statistics published by the Central Bank, there has been a significant increase in the amount of funds invested by Islamic banks in securities. For instance, the amount of funds invested by Islamic banks in securities reached forty six billion seven hundred million Emirati dirham by the end of 2017. However, the amount of funds invested by Islamic banks in securities reached sixty one billion seven hundred million Emirati dirham by the end of 2018. The latter increase is represented in 15 billion Emirati dirham. The latter increase is represented by a rate of $32 \%$.

\section{Previous Studies}

Al-Rafeeq (2010) found that Islamic banks can play a significant role in financing enterprises. He found that financing enterprises by Islamic banks shall have a statistically significant positive impact on the growth of the gross domestic product. He also found that Islamic finance has a statistically significant positive impact on the government spending. He found that Islamic banks play a significant role in achieving economic development. Aziz (2010) found that Islamic banks play a significant role in achieving development. He states that the transactions of Islamic banks are based on Musharakah. He suggests that Islamic banks share the financial risk with customers when investing money in the form of direct investment.

Mashbab (2015) found that private banking credit has a statistically significant impact on the gross domestic product. He found that there's a significant relationship between these variables. He also found that banking 
credit plays a minimal role in interpreting the changes occurring in the gross domestic product. He found that private banking credit has a minimal positive impact on economic activity. Arafeh (2017) found that there's a positive relationship between the amount of funds invested in Murabaha in the Islamic finance sector from one hand and the gross domestic product in Sudan from another hand. For instance, an increase by $1 \%$ in the amount of fund invested in Murabaha in the Islamic finance sector shall lead to an increase in the gross domestic product by a rate of $0.65 \%$. The latter researcher also found that the amount of fund invested in Murabaha in the Islamic finance sector in Sudan increases annually by a rate of $2.22 \%$. He also found that the gross domestic product in Sudan increases annually by a rate of $4.5 \%$.

Razy (2012) found that Islamic banks play a significant role in raising the amount of national savings. He also found that Murabaha is the most prevalent product among the Islamic banks' products. He also found that Islamic banks focus on funding the short-term investments that provide revenues fast more than funding small and medium-sized enterprises in the industrial and agricultural sectors.

Zagh'lami and Kamal (2018) suggest that Islamic bank finance has a statistically significant impact on the gross domestic product in Malaysia. They suggest that Islamic bank finance plays a significant role in interpreting the change occurring in the gross domestic product in Malaysia. Al-Beka'i (2014) found that Islamic banks focus on funding the business, industrial, service, real estate and agricultural sectors respectively. Funding these enterprises shall participate in increasing the productivity levels of these sectors.

Meqdad and Halas (2005) found that Islamic banks in Palestine play a significant role in raising the amount of national savings. They found that Islamic banks in Palestine don't play a significant role in providing customers with credit facilities. Thus, that weakens the role the latter banks in achieving economic development. The latter researcher suggests that the latter banks must provide more attention to planning, Mudaraba and Musharakah. They suggest that providing such attention requires setting applicable rules and fundamentals that are clear. They recommend finding alternatives for Murabaha. Al-Ra'i (2011) suggests that Syrian banks focus much on the provision of short-term consumption funding. He suggests that the presence of a mortgage is the main condition that must be met to get an enterprise loan from Syrian bank. He suggests that the assets of Islamic banks have been increasing significantly during the recent couple of years.

Most of the previous studies suggest that Islamic banks and finance have a statistically significant positive impact on the growth of the gross domestic product. They also suggest that Islamic finance can significantly affect a state's economy. That represents an answer for the study's question.

\section{The Study's Methodology}

The researcher adopted a descriptive approach. He reviewed the relevant theoretical literature and previous studies. That was done to identify the impact of Islamic banks on the gross domestic product. The researcher also reviewed the statistical reports that include statistical data about Dubai. These reports were reviewed to collect information about the reality of Islamic finance and banks in Dubai.

The study's population consists from all the Islamic banks operating in the United Arab Emirates. The study's sample consists from 100 employees. The latter employees were selected from the credit facilities department of two Islamic banks located in Dubai. The latter banks are: (Emirates Islamic bank, and Dubai Islamic Bank). The characteristics of the study's sample are presented in table (1) below:

Table 1. The characteristics of the study's sample

\begin{tabular}{llll}
\hline & & Frequency & Percentage\% \\
\hline \multirow{4}{*}{ Gender } & Male & 67 & 67 \\
& Female & 33 & 33 \\
& Less than 10 years of experience & 22 & 22 \\
& $10-15$ & 62 & 62 \\
Academic qualification experience & More than 15 years of experience & 16 & 16 \\
& Diploma & 8 & 8 \\
& BA & 77 & 77 \\
& MA & 15 & 15 \\
& Total & 100 & 100 \\
\hline
\end{tabular}

Table 1 shows that $67 \%$ of the respondents are males, whereas $33 \%$ are females. It also shows that $62 \%$ of the 
respondents have 10-15 years of experience, whereas $22 \%$ of the respondents have less than 10 years of experience. It was found that $16 \%$ of the respondents have more than 15 years of experience. It was found that $8 \%$ of the respondents hold a diploma degree. It was found that $77 \%$ of the respondents hold a BA degree. It was found that $15 \%$ of the respondents hold a $\mathrm{PhD}$ degree.

The study's instrument is a questionnaire. It was developed based on the relevant theoretical literature and the previous studies that were reviewed. The latter questionnaire includes statements about the extent of contribution of Islamic banks in the gross domestic product. The latter questionnaire sheds a light on the nature of the provided credit facilities and the categories benefitting from such facilities.

The researcher aimed to identify the extent of contribution of Islamic banks in the achievement of economic growth. He aimed to explore that from the perspective of the employees who work at the credit facilities department of two Islamic banks located in Dubai. To meet the latter objective, the researcher selected two variables. These variables are: 1)-the credit facilities granted to small and medium-sized enterprises and 2)-the credit facilities granted to tourism enterprises.

\section{Data Statistical Analysis}

The researcher surveyed the attitudes of the employees who work at the credit facilities department of two Islamic banks in Dubai. That was done through calculating the means of the questionnaire's statements.

Table 2. The credit facilities granted to the owners of small and medium-sized enterprises

\begin{tabular}{|c|c|c|}
\hline Statement & $\begin{array}{l}\text { Arithmetic } \\
\text { mean }\end{array}$ & $\begin{array}{l}\text { Standard } \\
\text { deviation }\end{array}$ \\
\hline 1. The bank funds small and medium-sized enterprises & 3.96 & .424 \\
\hline $\begin{array}{l}\text { 2. There isn't any condition that hinders the owners of small and medium-sized enterprises from } \\
\text { getting funded }\end{array}$ & 3.99 & .758 \\
\hline $\begin{array}{l}\text { 3. There are special departments in the bank that are responsible for funding small and } \\
\text { medium-sized enterprises. }\end{array}$ & 3.47 & .558 \\
\hline $\begin{array}{l}\text { 4. There's a great demand for Islamic funding among the owners of small and medium-sized } \\
\text { enterprises }\end{array}$ & 3.97 & .822 \\
\hline The credit facilities are granted to the owners of newly established and existent enterprises. & 4.11 & .863 \\
\hline
\end{tabular}

Table 2 shows that the respondents' attitudes are positive towards the statements that concern small and medium-sized enterprises. That's because the means of all these statements are greater than 3 . Based on the standard deviations, it was found that there isn't much variance between the respondents' attitudes in this regard. It was found that Islamic banks play a significant role in the development of small and medium-sized enterprises. Thus, they play a significant role in raising the overall gross domestic product.

Table 3. The credit facilities granted to the owners of tourism enterprises

\begin{tabular}{|c|c|c|c|}
\hline \multicolumn{2}{|c|}{ Statement } & \multirow{2}{*}{$\begin{array}{l}\text { Arithmetic } \\
\text { mean } \\
\end{array}$} & \multirow{2}{*}{$\begin{array}{l}\begin{array}{l}\text { Standard } \\
\text { deviation }\end{array} \\
\end{array}$} \\
\hline 6. & The bank funds various types of tourism enterprises & & \\
\hline 7. & There isn't any condition that hinders the owners of tourism enterprises from getting funded & 3.93 & .256 \\
\hline & $\begin{array}{l}\text { There are special departments in the bank that are responsible for funding tourism } \\
\text { orises }\end{array}$ & 3.83 & .513 \\
\hline 9. & There's a great demand for Islamic funding among the owners of tourism enterprises & 3.01 & .000 \\
\hline 10. & The newly established and existent tourism enterprises benefit from Islamic funding & 3.97 & .521 \\
\hline
\end{tabular}

Table 3 shows that respondents' attitudes are positive towards the statements that concern tourism enterprises. That's because the means of all these statements are greater than 3. Based on the standard deviations, it was found that there isn't much variance between respondents' attitudes in this regard. It was found that Islamic banks play a significant role in the development of tourism enterprises. Thus, they play a significant role in raising the overall gross domestic product. 


\subsection{Testing the Study's Hypothesis}

Ha.1)- Islamic banks have a statistically significant impact on the gross domestic product (GDP) in Dubai.

Statistical analysis was conducted to test the study's hypothesis. Based on the results of the latter analysis, it was found that the calculated T value is 35.160 . It's greater than 1.64. Thus, the study's hypothesis is accepted. That means that Islamic banks have a statistically significant impact on the gross domestic product (GDP) in Dubai.

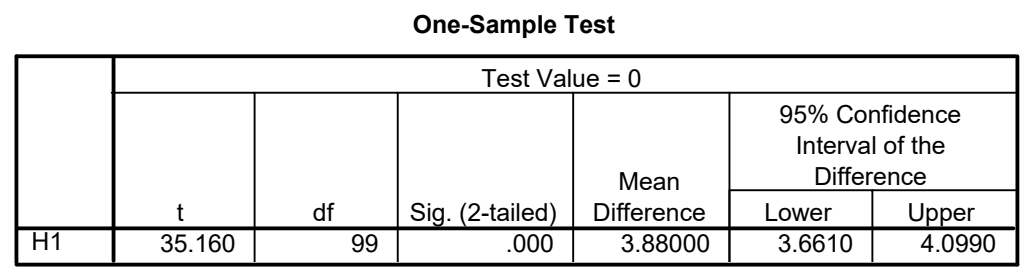

In the light of the aforementioned, it can be concluded that Islamic banks play a significant role in raising the gross domestic product (GDP) in Dubai in particular and the United Arab Emirates in general.

\section{Conclusion}

After analyzing data statistically, the researcher concluded that Islamic banks play a significant role in raising the gross domestic product (GDP) in Dubai in particular and the United Arab Emirates in general. Thus, the Islamic banking sectors can significantly affect the national economy of the United Arab Emirates (UAE). Therefore, the researcher believes that much attention should be granted to the Islamic banking sector.

\section{Recommendations}

The researcher recommends developing and innovating new funding, banking and investment products in the aim of meeting the demands of customers. These products mustn't violate the provisions of Sharia (Islamic law). In addition, the researcher recommends using the modern technologies and skills at banks. That shall participate in achieving development. He recommends conducting similar studies that seek exploring the impact of Islamic finance on key economic indicators.

\section{References}

Abu, S. A. (2018). The United Arab Emirates holds leading positions in terms of 5 Islamic economy indicators.

Al-Asali, S. M. (1998). The economy of Yemen and expected role of Islamic banks. The Journal of the Business and Economic, 10.

Al-Beka'I., A. (2014). The Islamic banking experience in Syria: reality and obstacles (2007-2011). Damascus University Journal for Economic and Legal Sciences, 30(1), 697-716. Retrieved from: http://damascusuniversity.edu.sy/mag/law/images/stories/1-2014/ar/697-716.pdf

Al-Nouri, M. (2009). The Islamic banking experience in Europe: orientations, challenges and prospects. A paper presented at the proceedings of the 19th Conference of the European Council for Fatwa and Research. Istanbul. Turkey.

Al-Rafeeq, M. (2002). The impact of Islamic bank finance on some macroeconomic variables and development in the Republic of Yemen. A paper presented at the proceedings of the Conference of the Faculty of Administrative Sciences. University of Dhamar. Yemen.

Al-Ra'i, T. M. (2011). The role of Islamic and conventional banks in the achievement of economic development in Syria. Unpublished MA thesis. Damascus University

Al-Tamimi, H., \& Al-Sanfi, A. (1995). Fundamentals about bank management (1st ed.). Sana', Yemen. Al-Hekma Al-Yamaneya publishing and distribution house.

Arafeh, A. A. M. (2017). The impact of finance - in the form of Murabaha - on the actual gross domestic product in Sudan: An empirical study. Unpublished MA thesis. Al-Jazeera University. Retrieved on 5-1-2019 from http://repo.uofg.edu.sd/handle/123456789/705?show=full

Aziz, M. (2010). The Islamic finance models and their impact on the economic activity: A case study in the Islamic Development Bank. Al-Gharee Journal for Economics and Administration Sciences, 4(19), 47-81. Retrieved on 5-1-2019 from http://www.uokufa.edu.iq/journals/index.php/ghjec/article/view/1865 
Khalaf, F. (2006). Islamic banks. $1^{\text {st }}$ edition. Jordan. Alam Al-kotob Al-Hadith publishing and distribution house.

Mashbab, G. (2015). The impact of private banking credit on the economic activity: A case study for Yemen. The Jordanian Journal for Administrative Sciences, 2(2).

Meqdad, M., \& Halas, S. (2005). The Role of Islamic Banks in Financing Economic Development in Palestine. IUJ Journal of Humanities Research, 13(1). 239-261.

Razy, M. A. D. (2012). The reality of investment and Islamic finance and the economic prospects of Islamic finance in Syria. Unpublished PhD dissertation. Damascus University.

Zagh'lami, M., \& Kamal, S. (2018). The Islamic banking financing and its effect on the Malaysian GDP gross domestic product during 2000-2016-An analytical and econometric study. The Journal of the Researcher in Economics, 8(1), 112-133.

Dubai Center for Statistics. (2018). The contribution of the Islamic economy in the gross domestic product in Dubai.

Retrieved

on

from:http://www.alkhaleej.ae/economics/page/0a30e271-00a0-48dd-b2c6-b89a187c2889\#sthash.XnymZuA v.dpuf

\section{Notes}

Note 1. The landowner shall permit the tenant to use his land in exchange for a share of the profits gained through selling the crops planted on the latter land.

Note 2. It's a transaction through which the purchaser orders the manufacturer to manufacture a certain customized product. However, the purchaser must provide the manufacturer with materials, goods or financial assets.

Note 3. It's an Arabic word derived from the word (Riba). It refers to the gain made in debit, or trade and considered unjust under the provisions of Sharia (the Islamic law).

\section{Copyrights}

Copyright for this article is retained by the author(s), with first publication rights granted to the journal.

This is an open-access article distributed under the terms and conditions of the Creative Commons Attribution license (http://creativecommons.org/licenses/by/4.0/). 